\title{
Measurements of physical parameters characterizing ESDs on solar cell and correlation between spectral signature and discharge position
}

\author{
V. Inguimbert, J. M. Siguier, G. Murat, S. Reyjal, J.C.Matéo-Vélez, P. Sarrailh, N. Balcon, D. Payan
}

\begin{abstract}
Electrostatic discharges on solar cells are possible cause of dramatic consequences such as secondary arcs responsible of definitive power losses. To cope with these significant implications, different approaches are followed such as design rules reducing voltage between adjacent cells, conductive layers or grouting to try to reduce ESDs triggering. However, ESDs on solar cells cannot be completely avoided and having a good knowledge of their characteristics is essential for prevention, prediction and modelling. In this paper, we describe how the plasma emitted during an electrostatic discharge on solar cell can be analyzed with dynamic tools such as triple probes and time-resolved optical spectroscopy. These techniques are used to obtain results on plasma density and electron temperature that can be compared with outputs from ESDs and flashover propagation models. While time-resolved optical spectroscopy is used on a single point (the point where optical fiber is focused on), triple probe is also used for spatial measurements. With this technique, electron density is measured at several distances from the discharge point providing both temporal and spatial information. In a second time, the optical signature measured by optical spectroscopy is correlated with SEM observations showing the existence of two kinds of triple points at the cell's edge. These two kinds of discharges have different optical signatures showing either elements from the active junction or from the substrate and rear electrode. These discharges are also distinguished by SEM observations and images of cell's edges confirm the previous results. These results show the importance of the silver back electrode and also of the eventual presence of covering glue on the position of the discharge. They provide information for models but let us also imagine possible mitigation methods.
\end{abstract}

Keywords-ESD; optical spectrometry; triple probe

\section{INTRODUCTION}

This study aims to improve knowledge of the physical phenomena involved in Electrostatic Discharges (ESD) particularly on solar arrays, but can be generalized to any powering equipment. This work is part of a comprehensive approach to understanding but also allow obtaining useful data for the development of numerical models of ESD (especially SPIS [1]) which need quantitative data (temperatures, densities ...). The underlying aim is to overcome some discharges by preventing phenomena participating to appearance and thus

J-M Siguier, V. Inguimbert, G. Murat, J.C.Matéo-Vélez and P. Sarrailh are with the Onera - The French Aerospace Lab, 31055 Toulouse, France (e-mail: virginie.inguimbert@onera.fr)

S. Reyjal is with INSA Génie Physique, Av Rangueil, Toulouse, France

N. Balcon and D. Payan are with CNES, 31401 Toulouse, France reduce the possibility of failure.

ESDs are usually characterized by macroscopic signatures, such as electrical signatures (Blow-off and Flashover), level of potential gradient and position (within a few millimeters) but physical quantities such as electron temperature or plasma density at inception point are not easy to produce. The most useful technique to obtain such data is optical spectrometry which was used formerly by different teams ([2] [3] [4]) but needs to work on transition modelling to get quantitative results. This technique mostly used in integrating the signal over the duration of the discharge [ref 1-3] can also be used as a function of time with a complex spectral and time resolved bench [5]. In this former paper, we had worked on correlation of optical plasma emission with the transition from ESD to secondary arc with a quite intrusive triggering setup. We have then developed a new triggering technique and worked on new samples adapted to this study allowing us to make optical spectrometry measurements on some and Scanning Electron Microscope (SEM) observations on the others [6]. In this paper, we present new results on similar samples correlating the optical signature with the position of the discharges. In addition, we have also used a dynamic plasma analysis technique through a triple Langmuir probe for determining electron temperature and plasma density. In a first section, the test setup, including samples and techniques are described. Then (section III), we will present the experimental results obtained and will conclude in the last part (section IV).

\section{DESCRIPTION OF THE TESTS}

\section{A. Tests samples}

Tests were performed on two kinds of samples built by Galileo. The first type (type 1) was a coupon made of a pair of AzurSpace $3 \mathrm{G}$ cells glued on honeycomb substrate with the same configuration of a solar array (see Fig. 1). These samples were used for optical spectrometry measurements. The second type (type 2, see Fig. 2) was made of a portion of the same cells whose size $(2 \mathrm{~cm} * 2 \mathrm{~cm})$ and shape (cell and epoxy substrate edges in the same plane) allowed it to be installed in the observation chamber of a SEM. 
(Abstract No140)

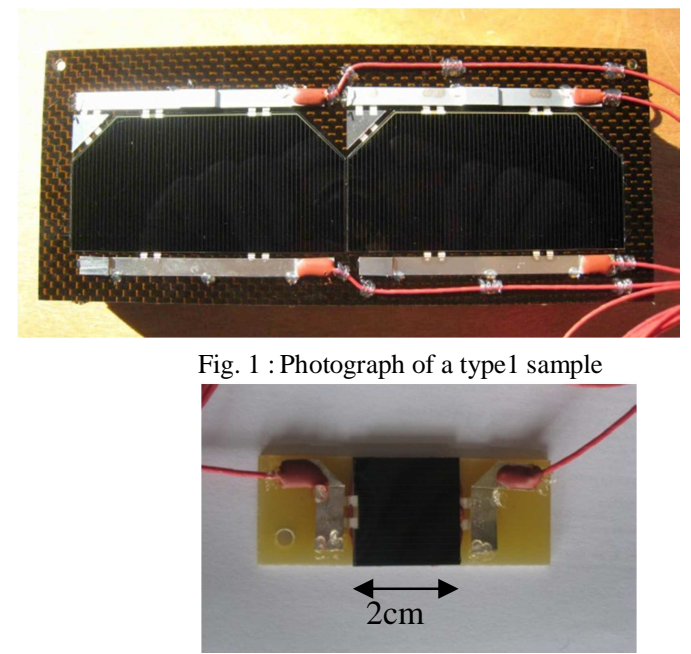

Fig. 2 : Photograph of a type2 sample

\section{B. Test facility}

All ESD experiments were conducted in JONAS chamber which is a $3.4 \mathrm{~m}$-long and $1.9 \mathrm{~m}$-diameter plasma chamber. The sample was brought to Inverted Potential Gradient (IPG) configuration thanks to the low density argon plasma. Hence, the sample was linked to a capacitance $\mathrm{C}_{\mathrm{sat}}$ representing the satellite capacitance and both were biased to a potential called $\mathrm{V}_{\text {bias }}$ equal to the value of the IPG. When a discharge occurred, the signal was measured thanks to a current probe (Pearson 2877) and recorded by an oscilloscope TDS3034. In the case of optical spectrometry, a specific method to trigger discharge was used which was described in [6]. To simulate the missing solar cells compared to a large panel and to represent the flashover current due to recollection by missing coverglasses of the current emitted from the cathodic spot, it is known that a simulator can be used. This simulator can be either physical [7] or electronic [8], [9]. In the case of spectrometry measurements, the physical simulator using a large surface of metallized polymeric film to simulate the missing assembly cell+coverglass has been used.

\section{Setup for optical spectrometry}

The bench used for time-resolved optical spectrometry is made of a $750 \mathrm{~mm}$-focal length monochromator from Horiba Jobin Yvon linked to Hamamatsu streak and CCD cameras. The ESD light is collected by an optical fiber placed close to the expected ESD site and sent to the monochromator where it is diffused by the grating. Two gratings are available: 100 or 1200 groves $/ \mathrm{mm}$. The light is then received by a streak camera C7700 which converts the photons into electrons sweeping them along an axis as a function of time. Then, electrons are again converted to photons and a 2D image is then generated whose horizontal axis is wavelength and vertical axis is time. This image is collected and recorded by the $1334 * 1024$ CCD matrix camera (C4742-98 model). The bench has been wavelength calibrated using a mercury lamp.

The streak camera can work with different time ranges which have to be defined before the test. The temporal range can be chosen from $10 \mathrm{~ns}$ to $10 \mathrm{~ms}$. However, the camera has to be triggered in advance with a delay in the same order of magnitude of the temporal window duration. That means that if we want to measure the first instants of the discharge, a triggering system has to be used, its response time being in the same order of magnitude of the expected time resolution.

The triggering technique which has been developed and tested is based on the idea of enhancing locally the potential gradient to force ESD to occur. The sample is placed in IPG situation by plasma with a value of $\mathrm{V}_{\text {bias }}$ slightly below the ESD threshold. A potential pulse is then applied locally through a metallic electrode placed on the coverglass. A schematic view of the setup which has been widely described in [5], is given in Fig. 3 .

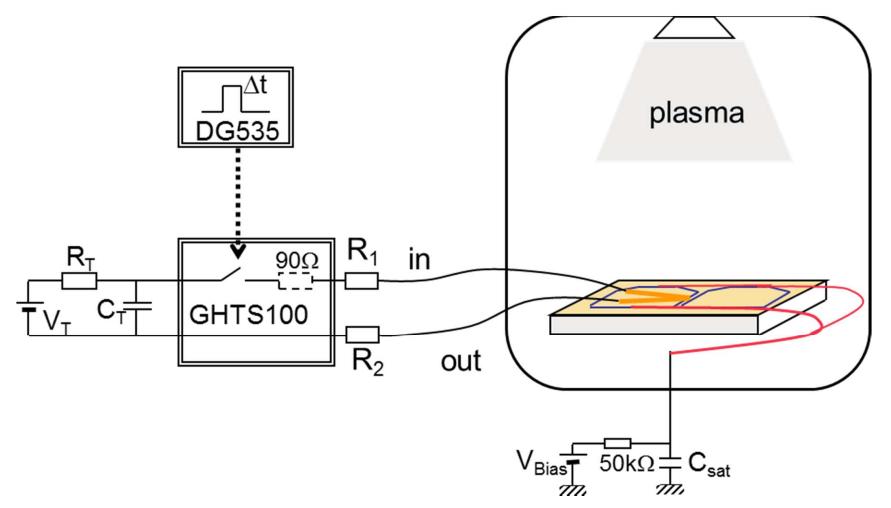

Fig. 3 : schematics of the triggering system

\section{Triple probe measurements}

Classical Langmuir probe needs to sweep biasing voltage to measure collected current and evaluate plasma parameters. In the case of high speed moving plasma bubble, this method cannot be used. In this situation, it necessary to use a system with static potentials. That is the case of triple probe method which uses 3 floating electrodes biased one to each other to potentials allowing separating different plasma populations. This method has shown all its interest in [10]. A schematic view of the triple probe system is shown on Fig. 4

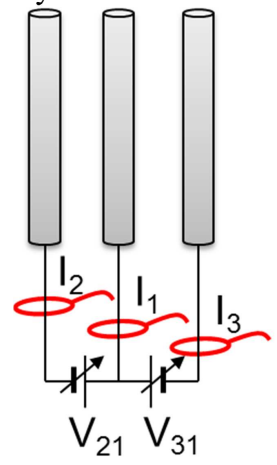

Fig. 4 : schematics of the triple probe system

Electrodes size and distance have to be adapted to the characteristics of the plasma under study. In order to make an analysis of the plasma at different distances from the cathodic spot, 2 kinds of probes have been built and used. Their features are given in TABLE I. The potential differences were 


\section{(Abstract No140)}

applied with batteries and the currents measured by Pearson 2877 current probes.

TABLE I. FEATURES OF THE DIFFERENT PROBES DEPENDING ON THEIR DISTANCE FROM THE CATHODIC SPOT

\begin{tabular}{|c|c|c|c|}
\hline $\begin{array}{c}\text { Distance from } \\
\text { cathodic spot }\end{array}$ & $\begin{array}{c}\text { Electrode } \\
\text { length }\end{array}$ & $\begin{array}{c}\text { Electrode } \\
\text { diameter }\end{array}$ & $\begin{array}{c}\text { Distance } \\
\text { between } \\
\text { electrodes }\end{array}$ \\
\hline $20 \mathrm{~mm}$ & $15 \mathrm{~mm}$ & $0,9 \mathrm{~mm}$ & $3 \mathrm{~mm}$ \\
\hline $190 \mathrm{~mm}$ & $80 \mathrm{~mm}$ & $10 \mathrm{~mm}$ & $75 \mathrm{~mm}$ \\
\hline $330 \mathrm{~mm}$ & $80 \mathrm{~mm}$ & $10 \mathrm{~mm}$ & $75 \mathrm{~mm}$ \\
\hline
\end{tabular}

We first applied and validated this technique and the 2 kinds of triple probes in 2 different plasma conditions. The smallest one in a quite dense plasma source (used to simulate the plasma of an electric thruster) and the biggest one in a LEO-like plasma. These probes were then used here to characterize high speed expanded plasma such as the one of ESDs.

\section{E. Pre/Post ESD observations by SEM}

As in [6], pre and post ESD observations have been made on kind of sample $n^{\circ} 2$ (the smallest). On these samples, several discharges have been obtained and observations at high resolution have been performed by SEM. Images were then reconstructed assembling different images. The microscope was a JEOL LV 5310. Images were obtained with $20 \mathrm{kV}$ electrons in Low Vacuum $(0.2 \mathrm{hPa})$ and EDX analysis were performed pointing specific points at low pressure $\left(10^{-5} \mathrm{hPa}\right)$. Hence, imaging at low pressure was not possible due to effects of surface charging and metallization of the sample to avoid this issue was not possible because the sample would not have been reusable for ESD. These observations needed to define areas on the samples to be observed prior to the ESDs and where one ESD would be produced in order to make observations prior to the test and then afterwards. These different operations were very time-consuming and were performed only a small amount of times.

\section{RESULTS}

\section{A. Position of the discharges}

In a former study [6], we have shown that different optical signatures could be recorded on our samples. Either the spectra showed the presence of the cell constituting elements and particularly active part of the cell (epitaxial zone) such as Germanium, Gallium, Indium. Or, the optical signature was dominated by the presence of silver lines all along the discharge duration. These last signatures were attributed to discharges occurring on the silver back electrode after ESD sites have been eroded on the top of the cell or because the DC93500 glue overflew on the cell. A schematic view of the cell given on Fig. 5 presents the different possible triple points depending if the glue is overflowing or not.

However, the observations by SEM did not confirm this assumption. Even on cut cell where no glue could hide triple points at epitaxial zone/glue/vacuum junction, only ESDs at the bottom of cell were observed.

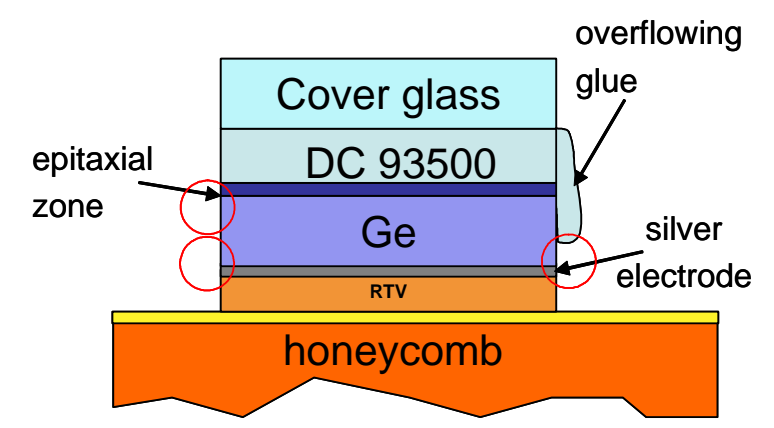

Fig. 5 : schematics of the cell with a view of possible triple points depending if the glue is overflowing or not.

It was then decided to work on a pristine sample and in this complementary study, a new phenomenon was observed which is presented on the next figures.

The first presented ESD presented here has been obtained in the experimental conditions given in TABLE II. :

TABLE II. EXPERIMENTAL CONDITIONS FOR OBTAINING ESD85

\begin{tabular}{|c|c|c|c|}
\hline $\begin{array}{c}\text { Central } \\
\text { wavelength }\end{array}$ & $\begin{array}{c}\text { Integration } \\
\text { time }\end{array}$ & Csat/ Vsat & FO simulator \\
\hline $500 \mathrm{~nm}$ & $100 \mu \mathrm{s}$ & $100 \mathrm{nF} /-1200 \mathrm{~V}$ & Kapton $1 \mathrm{~m}^{2}$ \\
\hline
\end{tabular}

The raw data measured during this discharge, i.e. the CCD image is given in Fig. 6. We can see, not only very rich spectra but also that these spectra change considerably along the discharge duration.

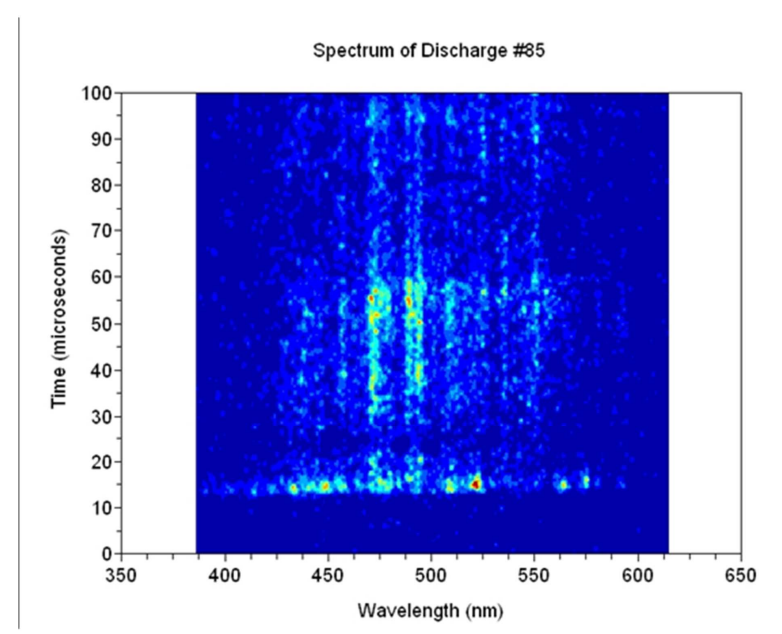

Fig. 6 : Image measured by CCD camera during ESD\#85

The data are integrated and spectra extracted from previous results as we can see on next figure which shows integrated spectra in two time slots, first at the early beginnings of the discharge $(17-20 \mu \mathrm{s})$ and during its maximum of emission $(20-60 \mu \mathrm{s})$. 
(Abstract No140)

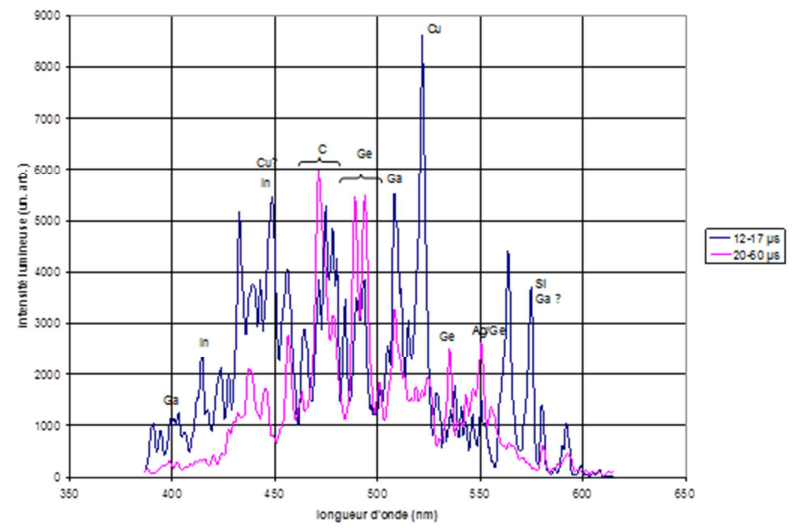

Fig. 7 : Spectra extracted from Fig. 6 (ESD\#85) integrating the result in two different time slots $(12-17 \mu$ s and $20-60 \mu$ s)

The interpretation of the peaks is not fully complete, however, it is quite obvious that the spectrum in the early phase of the discharge is rich and shows the presence of elements from the active part of the cell, while the second is mainly governed by the presence of germanium and silver lines.

This light signature suggests that the discharge starts from the top of the cell (presence of copper, gallium, indium, component glue...) and then shifts to the cell main component $(\mathrm{Ge})$ and silver back electrode $(\mathrm{Ag})$.

The time evolution of some of the main lines is shown on Fig. 8 with the discharge current (BO+FO). The first element appearing comes from the copper electrode but disappears to stay in the measurement noise during the rest of the discharge. The optical signals follow the electrical signature.

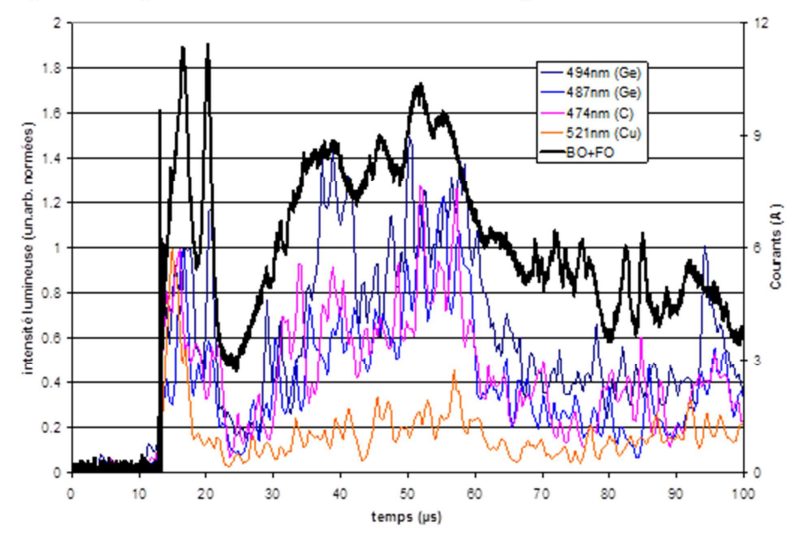

Fig. 8 : Time evolution of four lines during ESD\#85. Comparison with electrical signature $(\mathrm{BO}+\mathrm{FO})$

One of the following discharges has a very similar result but this time, the wavelength window is centered on another value $(600 \mathrm{~nm})$ allowing us to see better the presence of silver. This ESD has been obtained in the experimental conditions given in TABLE III.

TABLE III. EXPERIMENTAL CONDITIONS FOR OBTAINING ESD87

\begin{tabular}{|c|c|c|c|}
\hline $\begin{array}{c}\text { Central } \\
\text { wavelength }\end{array}$ & $\begin{array}{c}\text { Integration } \\
\text { time }\end{array}$ & Csat/ Vsat & FO simulator \\
\hline $600 \mathrm{~nm}$ & $100 \mu \mathrm{s}$ & $100 \mathrm{nF} /-1200 \mathrm{~V}$ & Kapton $1 \mathrm{~m}^{2}$ \\
\hline
\end{tabular}

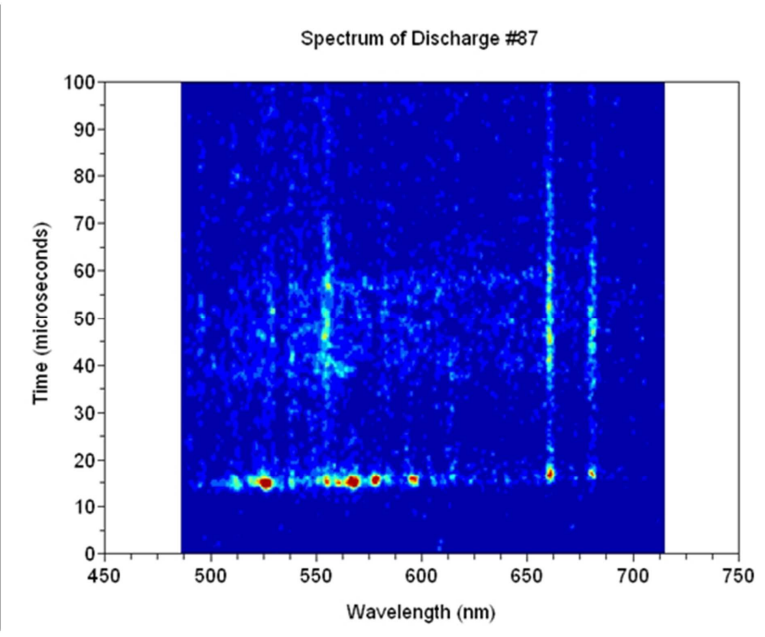

Fig. 9 : Image measured by CCD camera during ESD\#87

As before, the data are integrated and spectra extracted from raw image as we can see on next figure which shows integrated spectra in two time slots, first at the early beginnings of the discharge $(10-20 \mu \mathrm{s})$ and during the rest of th recorded emission $(20-100 \mu \mathrm{s})$.

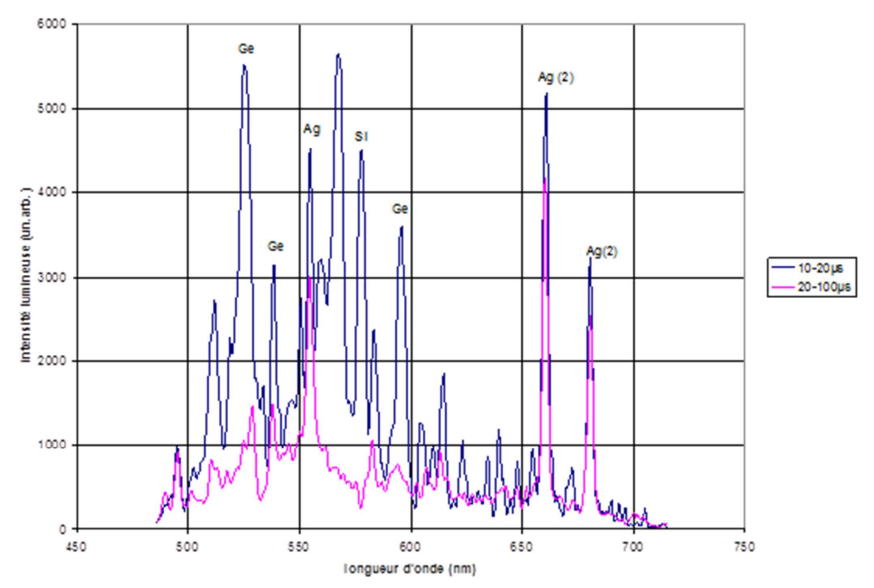

Fig. 10 : Spectra extracted from Fig. 9 (ESD\#87) integrating the result in two different time slots $(10-20 \mu$ s and $20-100 \mu$ s $)$

In this wavelength range, it is normal that we do not see lines from epitaxial zone since their major lines are more in a shorter wavelength zone. However, we see clearly a modification of the spectrum with emission of elements such as Germanium, silicon and silver and then only silver. In this case, the discharge can have moved from a tip on the germanium (including maybe epitaxial area) to the silver back electrode.

We have tried to correlate these results with SEM observations. However, he observations on the samples used for spectrometry was not possible (due to their size but mainly due to the fact that a lot of discharges have been produced in the same point. For the observations, we need to be sure that only a single discharge has occurred on a single area. For this purpose, we have used the small samples presented in section 


\section{(Abstract No140)}

II.A. On the sample, observations were made prior to the ESD test and after. In a first step, 4 discharges were obtained on cell's edge. These resultas were already presented in [6]. On these 4 ESDs performed on the edge of the cell with different values of $\mathrm{C}_{\text {sat }}$, only 2 were identified. They were situated on the silver back electrode. However, on this sample, we could see clearly with the SEM observations, that the glue between the cell and the coverglass (DC93500) overflowed on the cell and hided the top of the cell.

After this result and following the previous study by optical spectroscopy, it was decided to perform discharges on an ideal edge of cell i.e. without any overflowing glue. For this purpose, the previous sample was cut in the middle and the edge polished to obtain a very clean stack of layers.

In these conditions, 3 ESDs were performed on one side and 7 on the other piece.

The following table summarizes the different results:

TABLE IV. EXPERIMENTAL CONDITIONS FOR OBTAINING THE DISCHARGES ON CUT CELL

\begin{tabular}{|c|c|c|c|c|}
\hline $\begin{array}{c}\text { Side- } \\
\text { number }\end{array}$ & Csat/ Vsat & $\begin{array}{c}\text { Available } \\
\text { energy } \\
1 / 2 \mathrm{C}_{\text {sat }} V_{\text {bias }}{ }^{2}\end{array}$ & $\begin{array}{c}\text { Available } \\
\text { charge } \\
\mathrm{C}_{\text {sat }} V_{\text {bias }}\end{array}$ & ESD position \\
\hline $1-1$ & $150 \mathrm{nF} /-500 \mathrm{~V}$ & $18.75 \mathrm{~mJ}$ & $75 \mu \mathrm{C}$ & Not identified \\
\hline $1-2$ & $10 \mathrm{nF} /-500 \mathrm{~V}$ & $1.25 \mathrm{~mJ}$ & $5 \mu \mathrm{C}$ & Not identified \\
\hline $1-3$ & $50 \mathrm{nF} /-500 \mathrm{~V}$ & $9 \mathrm{~mJ}$ & $30 \mu \mathrm{C}$ & $\begin{array}{c}\text { Bottom of the } \\
\text { cell }\end{array}$ \\
\hline $2-1$ & $\begin{array}{c}100 \mathrm{nF} /- \\
1100 \mathrm{~V}\end{array}$ & $60.5 \mathrm{~mJ}$ & $110 \mu \mathrm{C}$ & Bottom \& top \\
\hline $2-2$ & $150 \mathrm{nF} /-500 \mathrm{~V}$ & $18.75 \mathrm{~mJ}$ & $75 \mu \mathrm{C}$ & Bottom \\
\hline $2-3$ & $\begin{array}{l}100 \mathrm{nF} /- \\
1100 \mathrm{~V}\end{array}$ & $60.5 \mathrm{~mJ}$ & $110 \mu \mathrm{C}$ & Not identified \\
\hline $2-4$ & $\begin{array}{c}100 \mathrm{nF} /- \\
1400 \mathrm{~V}\end{array}$ & $98 \mathrm{~mJ}$ & $140 \mu \mathrm{C}$ & Bottom \\
\hline $2-5$ & $100 \mathrm{nF} /-800 \mathrm{~V}$ & $32 \mathrm{~mJ}$ & $80 \mu \mathrm{C}$ & Bottom \\
\hline $2-6$ & $\begin{array}{c}100 \mathrm{nF} /- \\
1100 \mathrm{~V}\end{array}$ & $60.5 \mathrm{~mJ}$ & $110 \mu \mathrm{C}$ & Bottom \& top \\
\hline $2-7$ & $100 \mathrm{nF} /-960 \mathrm{~V}$ & $46.1 \mathrm{~mJ}$ & $96 \mu \mathrm{C}$ & Top \\
\hline
\end{tabular}

The first example is the discharge1-3. For this discharge, the sample edge has been scanned completely by SEM prior and after the ESD. Images taken through the SEM were then rebuilt to form a single image. The result is given on Fig. 11.

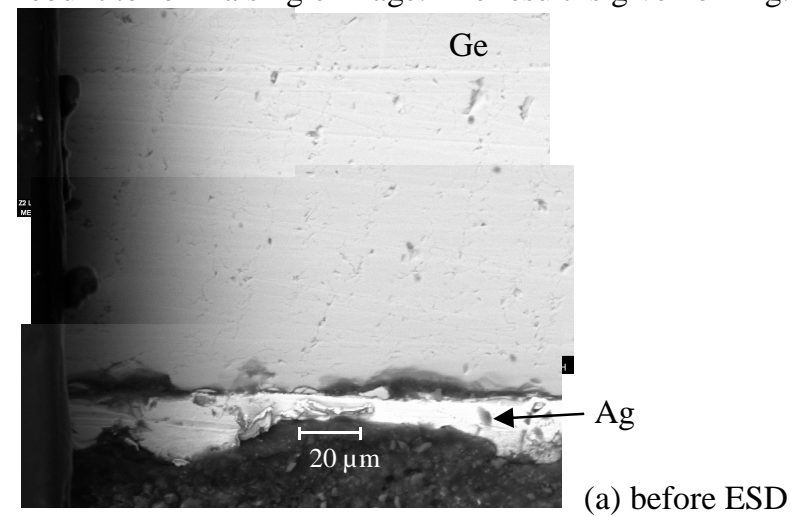

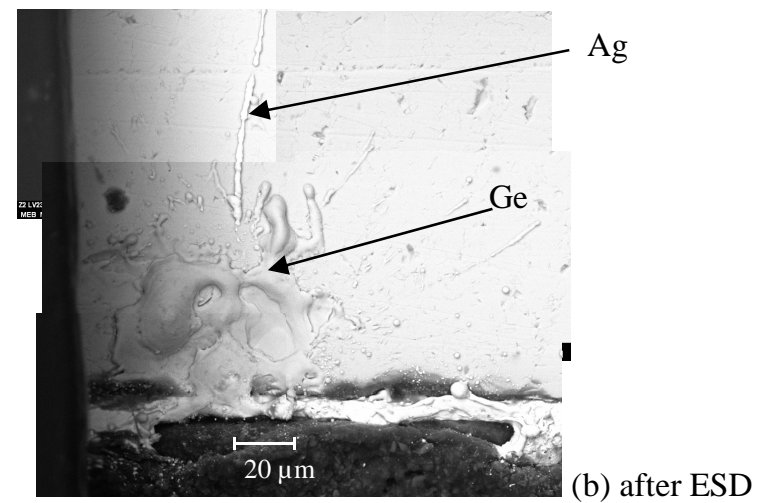

Fig. 11 : Images of the same zone on the cut edge of the cell before (top) and after (bottom) ESD\#1-3.

The EDX analysis in different points shows that this discharge involved mainly germanium and silver materials.

Another example is discharge \#2-1 given on Fig. 12.

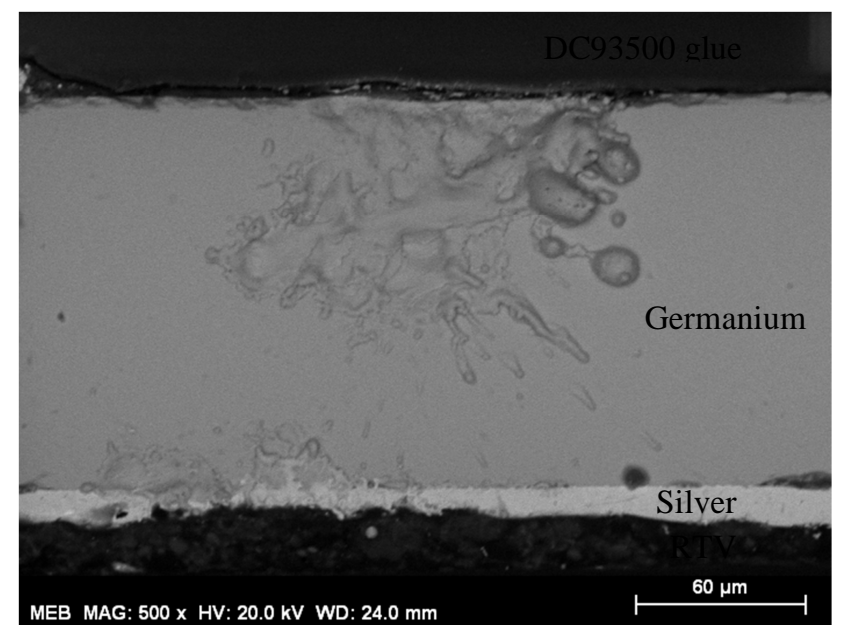

Fig. 12 : Image of ESD\#2-1

This image shows traces of the discharge both on top of the cell and on the bottom i.e. on the silver back electrode. The EDX analysis in different points shows that fused material at the top of the cell is essentially germanium and at the bottom, mainly silver.

These observations are in agreement with results obtained by optical spectrometry since most of the observed discharges occurred on the silver back electrode. The last observation (see Fig. 12) does confirm that discharge can migrate from one position (certainly the top of the cell) to another (the back electrode in silver). The shifting from the germanium to the silver can be either thermal or electrical. From thermal point of view, the boiling point of germanium is higher from silver's (3106K and 2435K respectively) and cathodic spot should then migrate to the material with the lowest boiling point. From an electrostatic point of view, this migration can also be attributed to the high difference of conductivity of these materials (respectively 2 and $6.10^{7} \Omega^{-1} \cdot \mathrm{m}^{-1}$ at room temperature) inducing a greater ease of the current to flow by the back electrode than through the germanium. 


\section{(Abstract No140)}

\section{B. ESD plasma characterization}

The discharges obtained on the solar cells coupons were also characterized with triple probe method. As told in the description of the setup, two kinds of triple probes were used depending on the position from the discharge point. Measurements were performed on the current probes given in Fig. 4. During the experimental test, the biasing potential Vbias varied from $-800 \mathrm{~V}$ to $2.2 \mathrm{kV}$ and Csat value first set to $100 \mathrm{nF}$, was then reduced to $330 \mathrm{pF}$ because during the blow-off and the flashover, the probe underwent a dV/dt of a few hundred volts that strongly disturbed the current collected plasma. After reducing the value Csat to $330 \mathrm{pF}$, the triple small probe was subjected to a variation of potential during the beginning of the blow-off which allowed the calculation of the characteristics of the plasma potential only after stabilization $(t>60 \mu \mathrm{s})$. The large triple probe, farthest, was no longer subject to potential changes and the measurement could therefore be carried out throughout the duration of flashover.

Electronic temperature Te of ESD plasma was deduced from currents and voltage values by the equation (1) [10]:

$$
\frac{I_{2}-I_{1}}{I_{3}-I_{1}}=\frac{1-\exp \left(\frac{e V_{2}}{k T_{e}}\right)}{1-\exp \left(\frac{e V_{3}}{k T_{e}}\right)}
$$

This equation cannot be directly solved because the voltage depends on the current. Calculation of Te can be obtained drawing the abacus of variation of Te as a function of the currents ratio $\left(\mathrm{I}_{2}-\mathrm{I}_{1}\right) /\left(\mathrm{I}_{3}-\mathrm{I}_{1}\right)$.

For plasma density $\mathrm{n}_{\mathrm{i}}$, it is calculated following the equation (2) and (3):

$$
\begin{aligned}
& J_{i}=n_{i} e \sqrt{\frac{k T_{e}}{m_{i}}} \\
& J_{i}=\frac{1}{S} \frac{I_{3}-I_{2} \exp \left(\frac{e \Delta V_{d}}{k T_{e}}\right)}{1-\exp \left(\frac{e \Delta V_{d}}{k T_{e}}\right)}
\end{aligned}
$$

With : $\mathrm{Ji}$ is the ion saturation current density; mi, the mass of a plasma ion, $\mathrm{k}$ the Boltzmann constant, e, the charge of an electron, $V_{d}=V_{2}-V_{3}$ and $S$ is the surface area of the probe.

Results obtained during this test campaign were very

\begin{tabular}{|c|c|c|c|c|c|c|}
\hline \multirow{2}{*}{$\begin{array}{c}\text { Distance } \\
\text { from } \\
\text { ESD } \\
(\mathrm{cm})\end{array}$} & \multirow{2}{*}{$\begin{array}{c}\text { Probe } \\
\text { type }\end{array}$} & \multirow{2}{*}{$\begin{array}{c}\text { Nb } \\
\text { ESDs }\end{array}$} & \multicolumn{2}{|c|}{ Te $(\mathrm{eV})$} & \multicolumn{2}{|c|}{$\mathbf{N}_{\mathrm{i}}\left(\mathrm{cm}^{-3}\right)$} \\
\hline & & & $\begin{array}{l}\text { Mean } \\
\text { value }\end{array}$ & $\begin{array}{l}\text { Standard } \\
\text { deviation }\end{array}$ & $\begin{array}{l}\text { Mean } \\
\text { value }\end{array}$ & $\begin{array}{l}\text { Standard } \\
\text { deviation }\end{array}$ \\
\hline 2 & small & 15 & 10.4 & 4.7 & $7.2 \mathrm{e} 15$ & $4.8 \mathrm{e} 15$ \\
\hline 19 & big & 19 & 7.8 & 2.2 & $3.14 \mathrm{e} 14$ & $2.0 \mathrm{e} 14$ \\
\hline 33 & big & 11 & 8.5 & 3.2 & $8.8 \mathrm{e} 13$ & $8.5 \mathrm{e} 13$ \\
\hline
\end{tabular}
numerous and a short summary is given in TABLE V.

TABLE V. RESULTS OBTAINED WITH THE TRIPLE PROBE SYSTEM

We can see that electronic temperature is not dependent from the distance from discharge point and equal to several $\mathrm{eV}$, in agreement with [3]. We clearly see also (see also Fig. 13) the density decrease as the distance from the ESD.

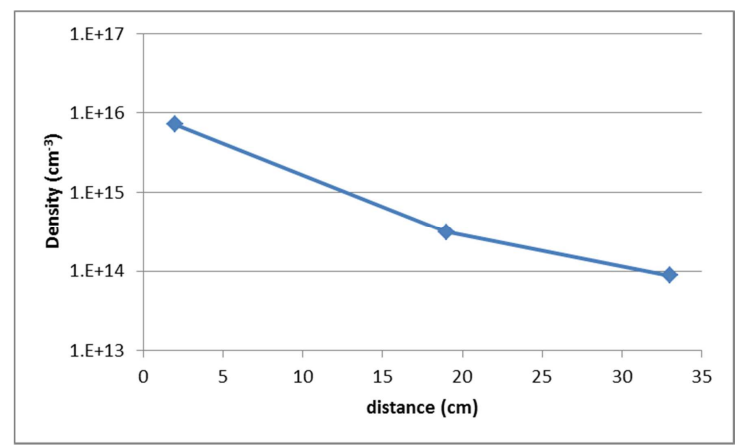

Fig. 13 : Evolution of plasma density as a function of distance from the discharge inception point

If we extrapolate the density to the inception point, we can reach a value of a few $10^{16} \mathrm{~cm}^{-3}$ which is in good agreement with results presented in [3].

\section{CONCLUSION}

We have shown in this study that the discharges obtained on our test samples showed ESD on the top of the cell at the triple point usually considered in the modeling [11] or, and even more frequently, on the bottom of the cell. We also saw that discharges starting on the top of the cell could migrate down, being due to thermal effects or to the better capacity of silver to drain the current. These observations have been performed by time-resolved optical spectroscopy but are confirmed by SEM observations cells edge after ESD. We have also seen that these results are certainly dependent from the technology since other experiments on different coupons can show quite different results [5] with a majority of discharges showing a signature corresponding to the epitaxial zone.

These results show the importance of shape of cells edge not only in the triggering of discharges but also on their development: triple points are multiple and all have to be considered for modelling and for mitigation systems development.

Lastly, with the help of triple probe, we have also characterized the plasma created during the discharge giving information directly usable in ESD modelling.

\section{ACKNOWLEDGMENT}

This work was supported by the French Space Agency CNES in the frame of R\&D program.

\section{REFERENCES}

[1] “http://dev.spis.org/projects/spine/home/spis." .

[2] B. L. Upschulte, W. J. Marinelli, K. L. Carleton, G. Weyl, E. Aifer, and D. E. Hastings, "Arcing of negatively biased solar cells in a plasma environment," J. Spacecr. Rockets, vol. 31, no. 3, pp. 493-501, May 1994.

[3] B. Vayner, D. C. Ferguson, and J. T. Galofaro, "Emission Spectra of Arc Plasmas," IEEE Trans. Plasma Sci., vol. 36, no. 5, pp. 2219-2227, Oct. 2008.

[4] E. Amorim, L. Levy, D. Sarrail, J.-P. Gardou, J.-L. Meunier, K. Bogus, and S. Vacquie, "Secondary 


\section{(Abstract No140)}

Discharges on Solar Arrays: Vacuum Arcs Across Adjacent Biased Cells," J. Spacecr. Rockets, vol. 42, no. 2, pp. 329-335, 2005.

[5] J.-C. Mateo-Velez, V. Inguimbert, K. Toyoda, D. Payan, and N. Balcon, "Time-Resolved Spectroscopy of Electrostatic Discharge and Secondary Arc Plasma on Spacecraft Solar Array," IEEE Trans. Plasma Sci., vol. 40, no. 2, pp. 359-367, février 2012.

[6] V. Inguimbert, J.-C. Mateo-Vélez, K. Toyoda, J.-M. Siguier, G. Murat, D. Payan, and N. Balcon, "A new setup for triggering ESDs on laboratory solar cells and study of electrostatic discharges by time-resolved Spectroscopy," Proceedings 12th SCTC, Kitakyushu, Jun-2012.

[7] V. Inguimbert, D. Sarrail, J.-C. Mateo-Velez, R. Reulet, L. Levy, F. Boulay, and D. Payan, "Electrostatic Discharge and Secondary Arcing on Solar Array \#x2014;Flashover Effect on Arc Occurrence," IEEE Trans. Plasma Sci., vol. 36, no. 5, pp. 2404-2412, Oct. 2008.

[8] K. Toyoda, T. Suzuki, T. Endo, H. Masui, and M. Cho, "Development of Flashover Current Simulator for ESD
Ground Testing Simulating GEO Environment," IEEE Trans. Plasma Sci., vol. 40, no. 2, pp. 321-323, février 2012.

[9] V. Inguimbert, P. Sarrailh, J.-C. Mateo-Velez, J.-M. Siguier, C. Baur, B. Boulanger, A. Gerhard, P. Pelissou, M. Sevoz, and D. Payan, "Measurements of the Flashover Expansion on a Real-Solar Panel-Preliminary Results of EMAGS3 Project," IEEE Trans. Plasma Sci., vol. Early Access Online, 2013.

[10] S.-L. Chen and T. Sekiguchi, "Instantaneous DirectDisplay System of Plasma Parameters by Means of Triple Probe," J. Appl. Phys., vol. 36, no. 8, pp. 2363-2375, Aug. 1965.

[11] P. Sarrailh, J.-C. Mateo-Velez, J. Roussel, B. Dirassen, J. Forest, B. Thiebault, D. Rodgers, and A. Hilgers, "Comparison of Numerical and Experimental Investigations on the ESD Onset in the Inverted Potential Gradient Situation in GEO," IEEE Trans. Plasma Sci., vol. 40, no. 2, pp. 368-379, février 2012. 
Measurements of physical parameters characterizing ESDs on solar cell and correlation between spectral signature and discharge position

V. Inguimbert ${ }^{1}$, J. M. Siguier ${ }^{1}$, G. Murat ${ }^{1}$, S. Reyjal ${ }^{2}$, J.C.Matéo-Vélez ${ }^{1}$, P. Sarrailh ${ }^{1}$, N. Balcon ${ }^{3}$, D. Payan ${ }^{3}$

${ }^{1}$ ONERA, The French Aerospace Lab., Toulouse, France

2 INSA Génie Physique, Toulouse, France

${ }^{3}$ CNES, The French Space Agency, Toulouse, France
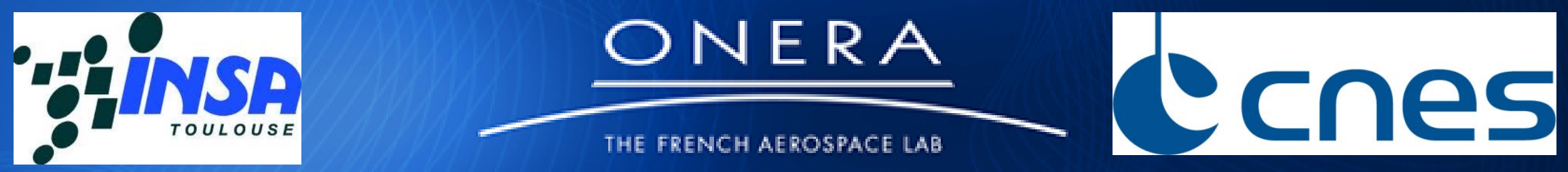

o n i n n o v a t i o n 


\section{Previous results} JouRnal of SeACBCRAFT AND RockEts
Vol. 31, No. 3, May-June 1994

\section{Arcing of Negatively Biased Solar Cells in a Plasma Environment}

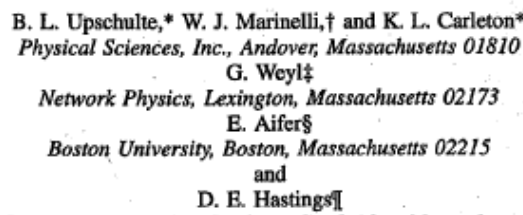

Massachusetts Institute of Technology, Cambridge, Massachusetts 02139

Correlation electrical and optical signatures

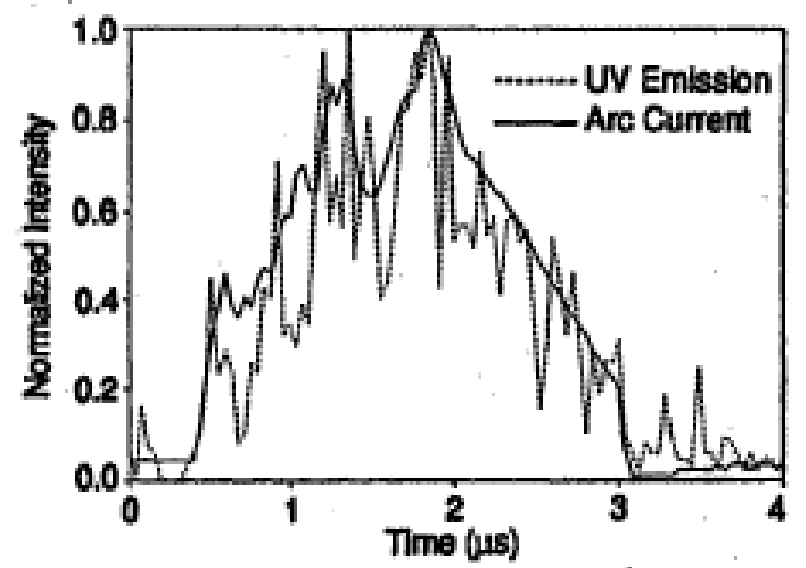

Fig. 8 Overlay of are temporal evolution viewed by both are current and UV light sensors.
IEEE TRANSACTIONS ON PLASMA SCIENCE, VOL. 36, NO. 5, OCTOBER 2008

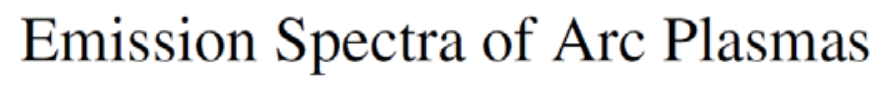

Boris Vayner, Dale C. Ferguson, and Joel T. Galofaro

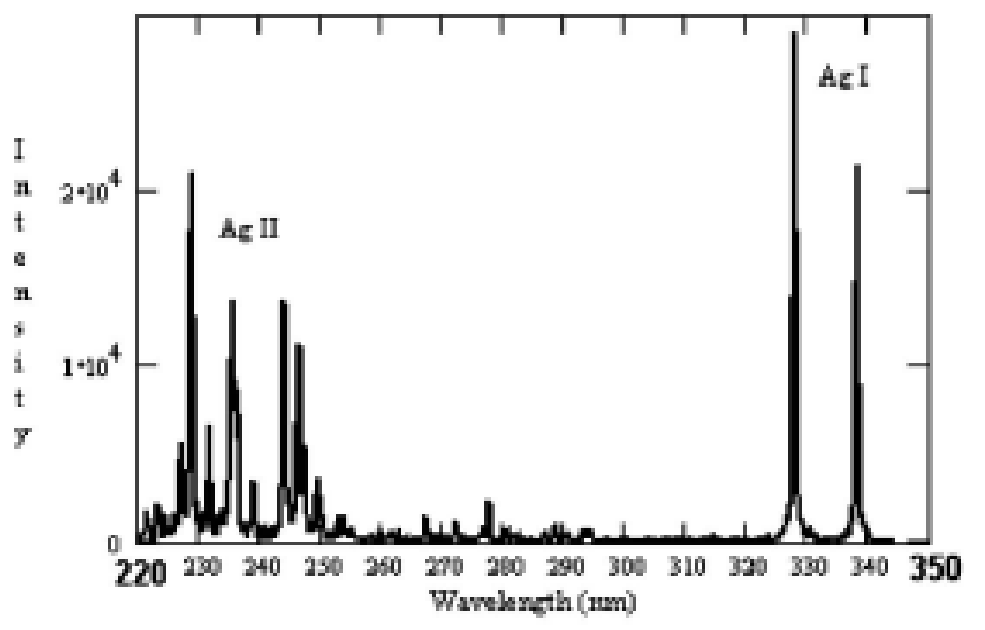

Spectra recorded at different times during the discharge 


\section{Previous results}

$>$ Triggering system from KIT (W needles)

J.-C. Mateo-Velez, et al. IEEE Trans. Plasma Sci., vol. 40, no. 2, pp. 359-367, feb-2012.

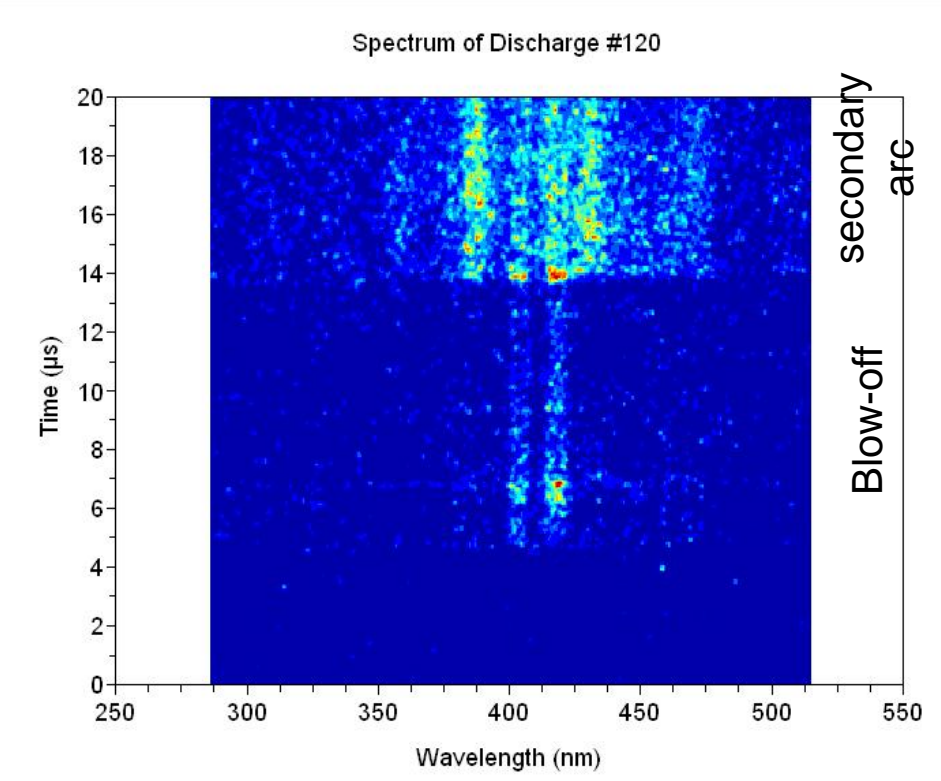

Observation of transition BO -> arc Invasive triggering system
$>$ Development of a new triggering system

V. Inguimbert et al, Proceedings 12th SCTC, Kitakyushu, Jun-2012.

Electrode $\mathrm{Cu}$
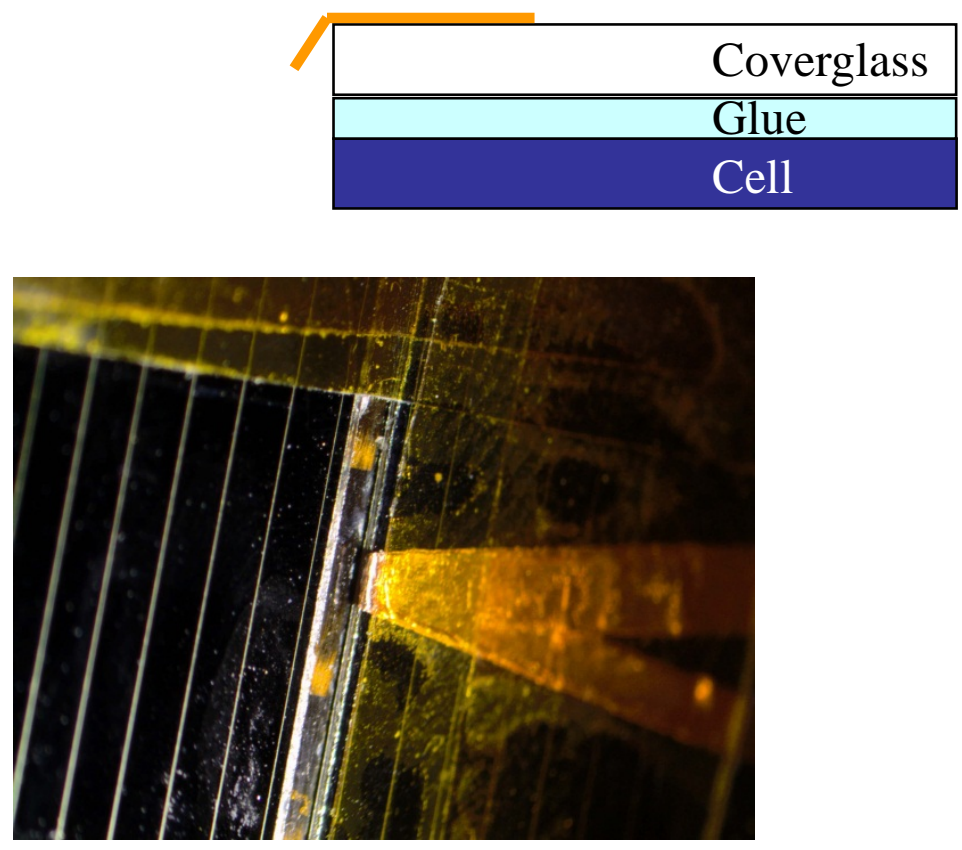

Different signatures of ESDs 
 \\ Experimental setup}

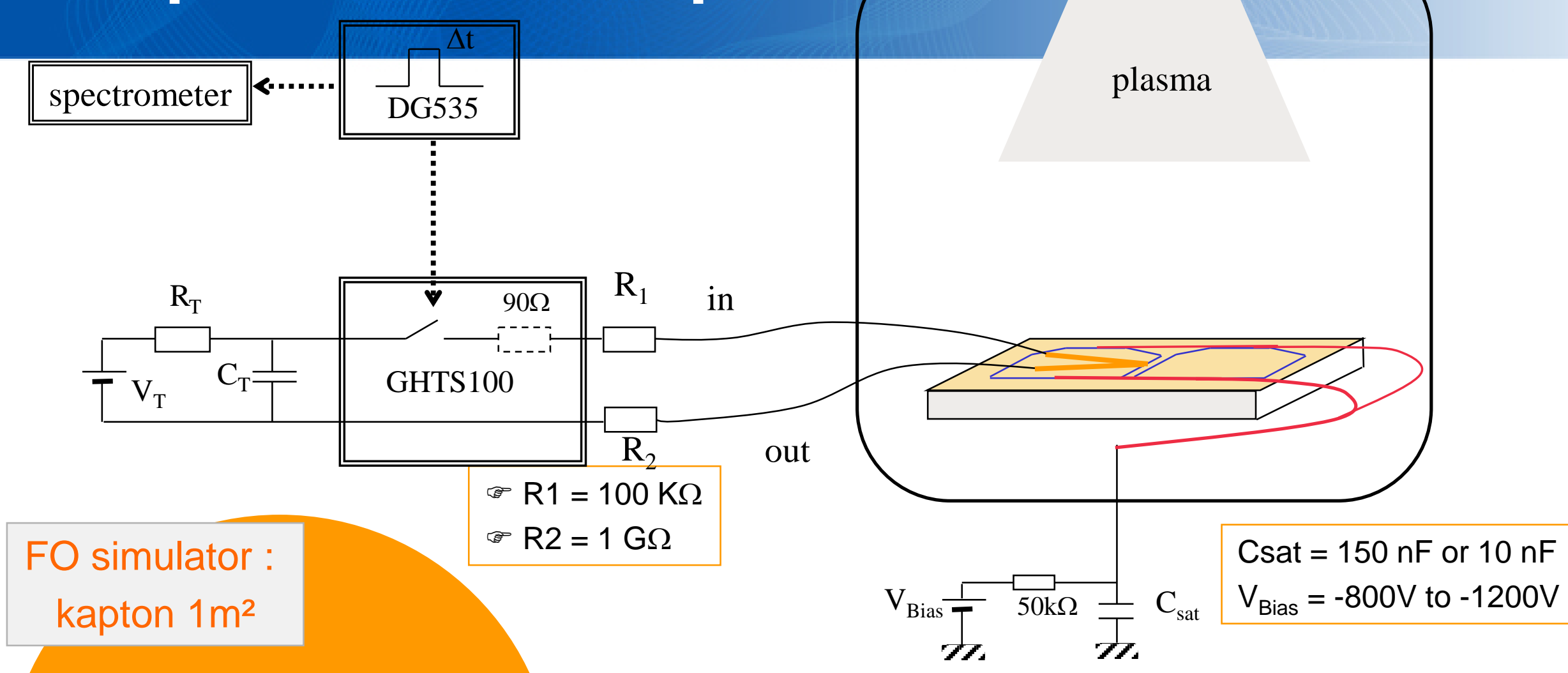

Aluminized kapton 50 $\mu \mathrm{m}$

$$
\mathrm{C}_{\mathrm{FO}}=470 \mathrm{nF}
$$

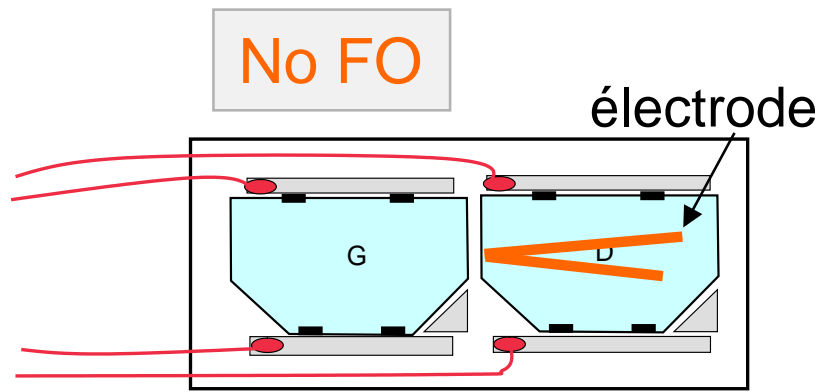




\section{Triple probe measurements}

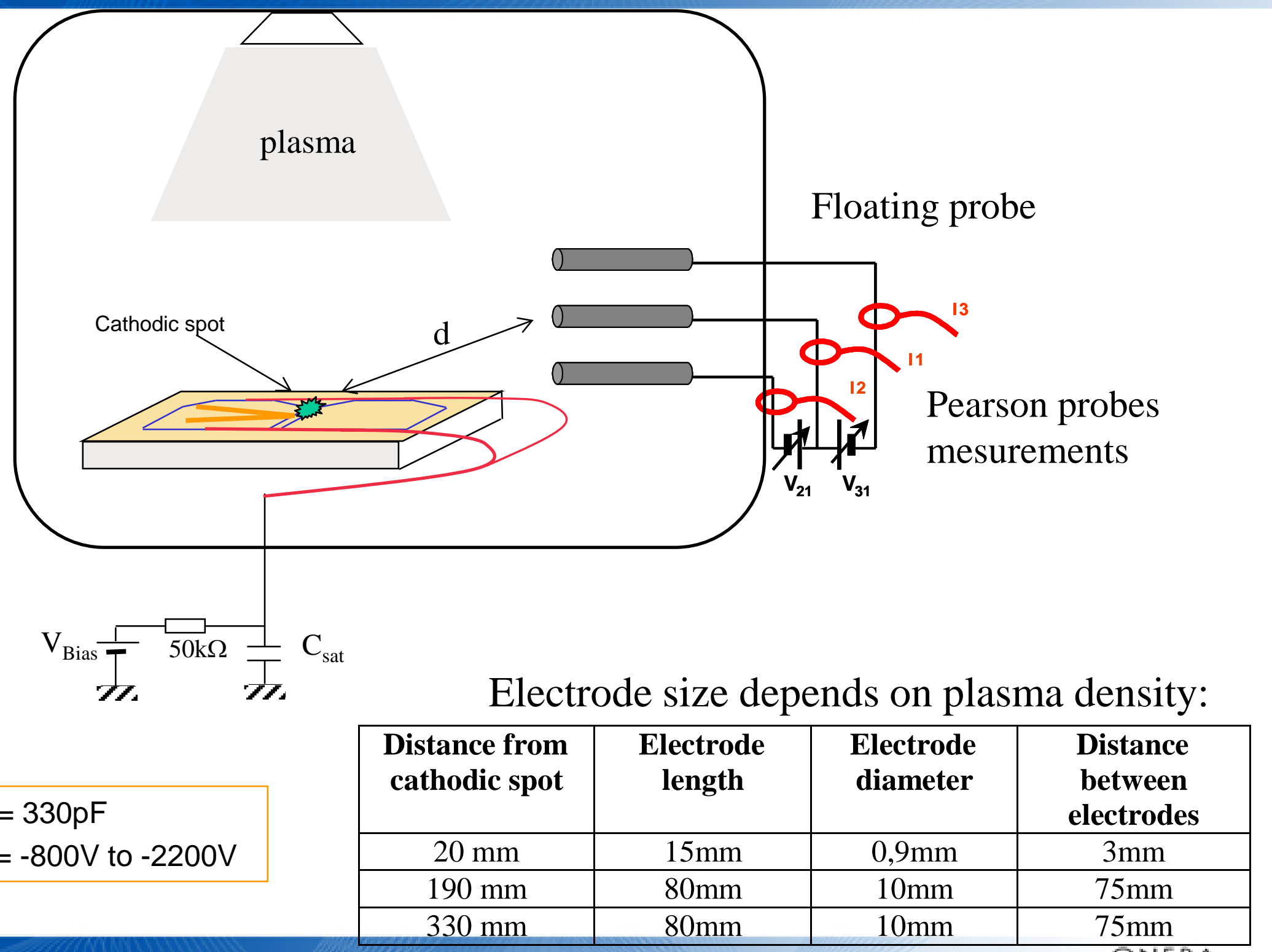

Csat $=330 \mathrm{pF}$

$V_{\text {Bias }}=-800 \mathrm{~V}$ to $-2200 \mathrm{~V}$ 


\section{View of the setup}

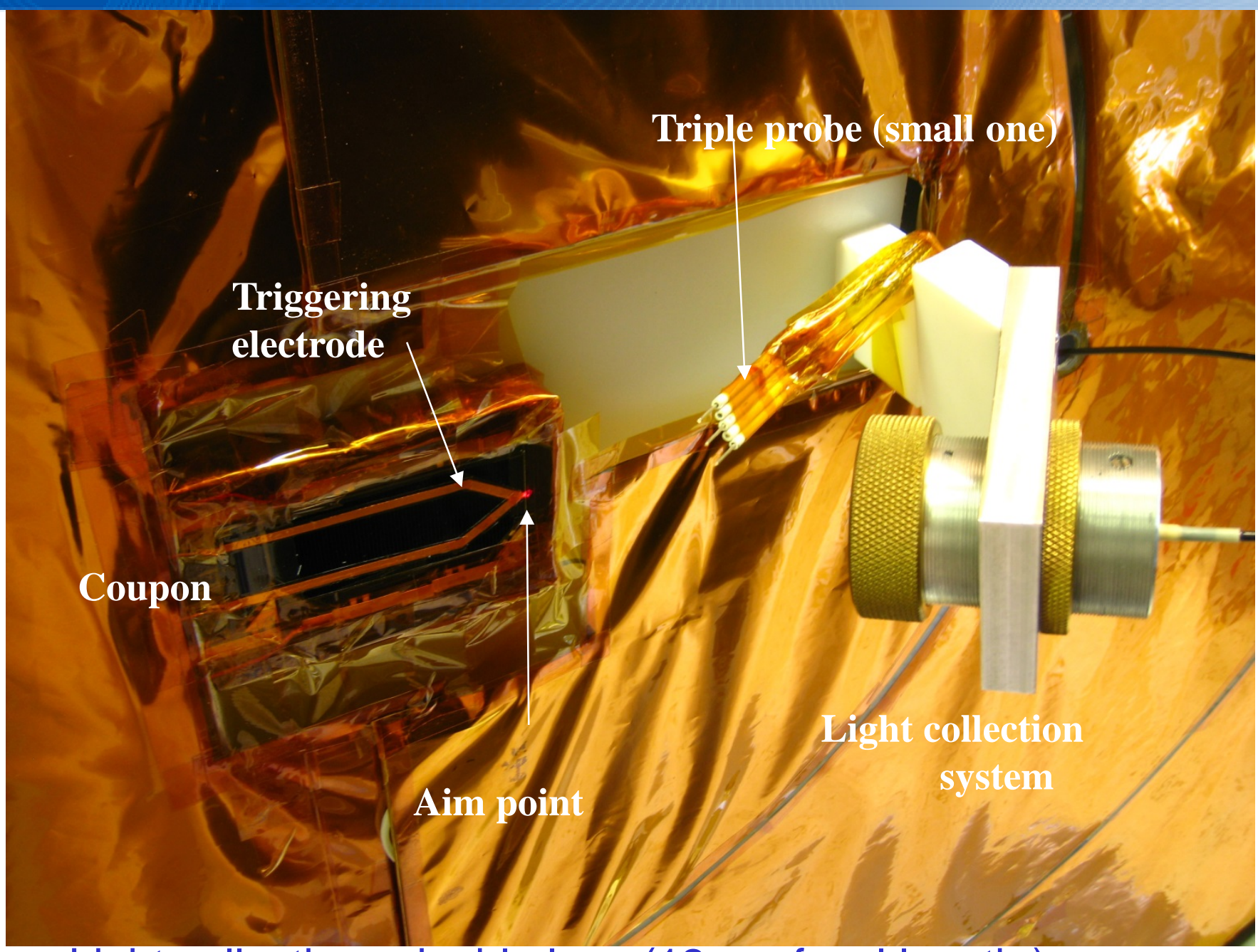

Light collection= double lens (12 cm-focal length ) Reduces disturbances, more precise sight point 


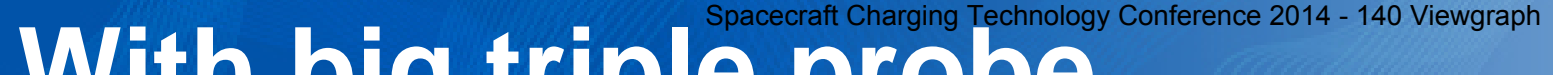 \\ With big triple probe}
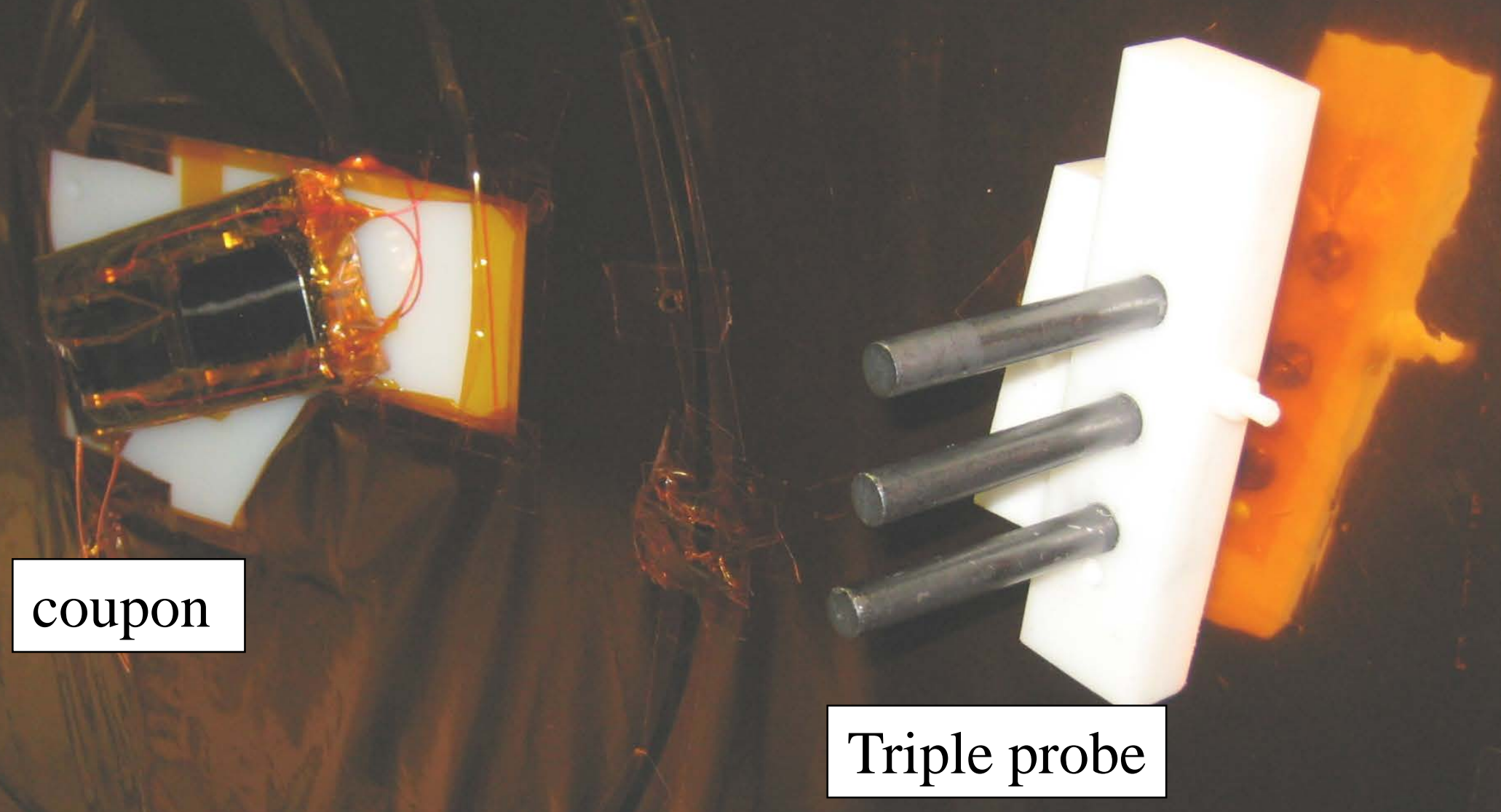


\section{Example of result : ESD58}
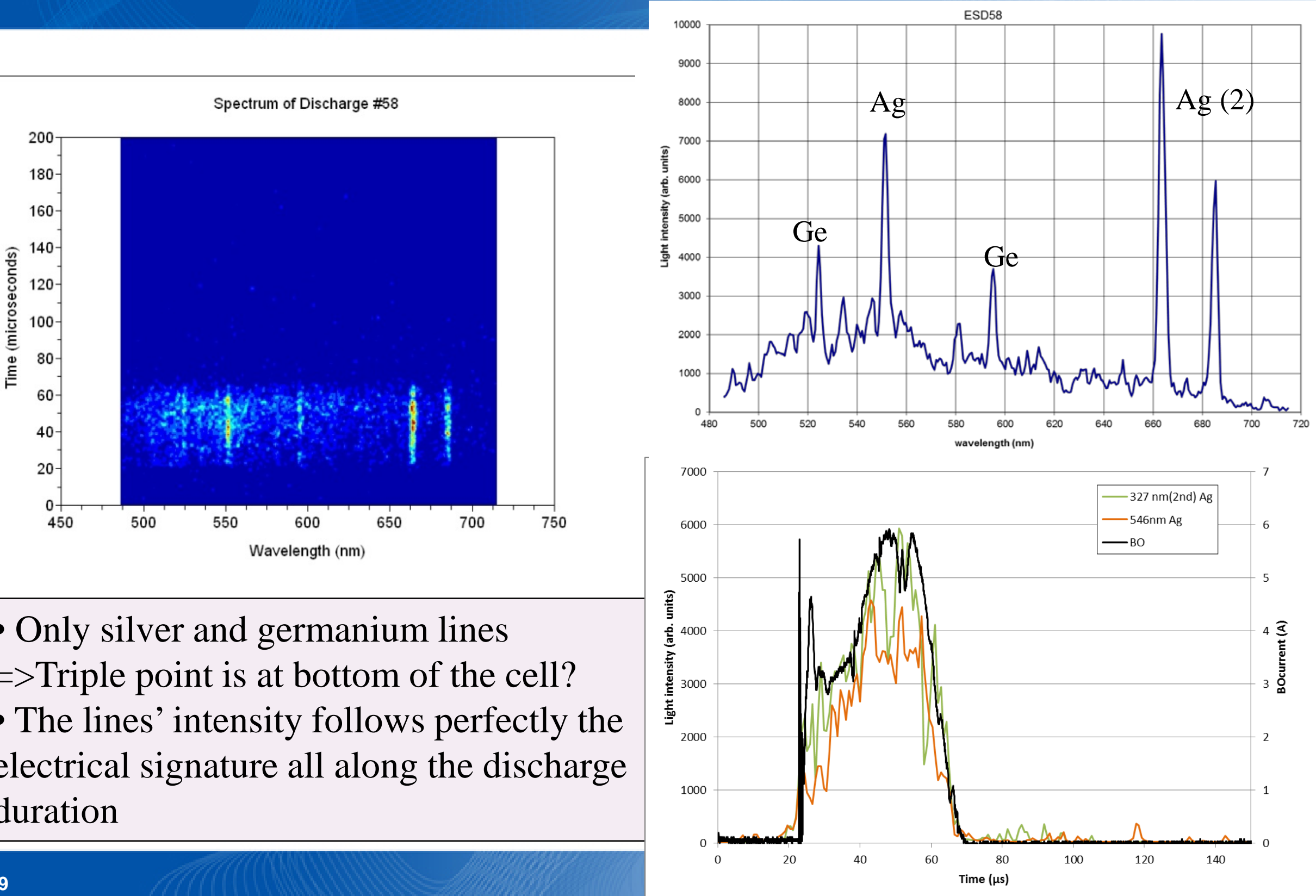

- Only silver and germanium lines $=>$ Triple point is at bottom of the cell?

- The lines' intensity follows perfectly the electrical signature all along the discharge duration 


\section{Example of result : ESD85}

Spectrum of Discharge \#85

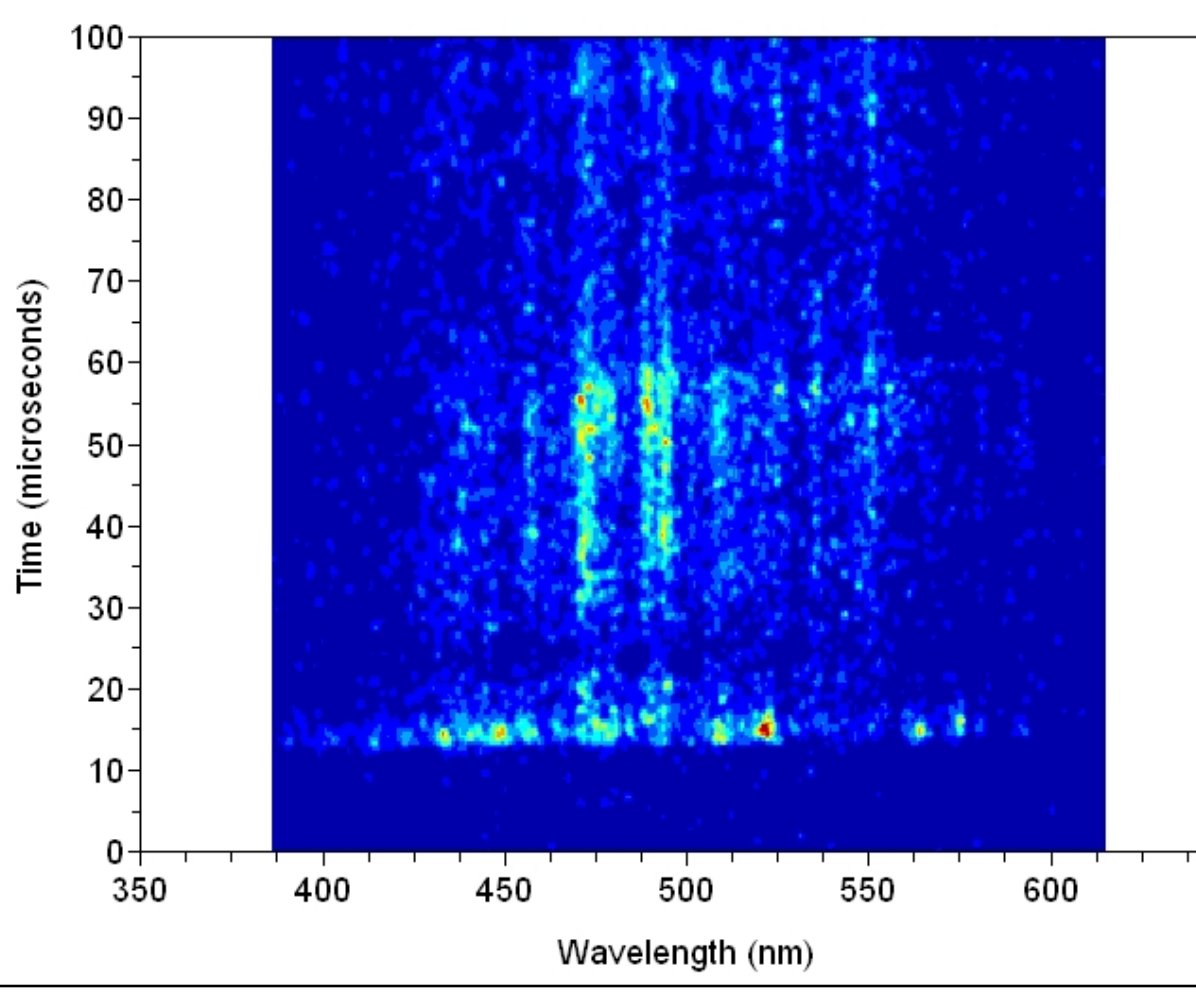

- spectrum very rich as the discharge begins (elements from epitaxial area) - semi-conductor at the origin of the discharge but migrates?

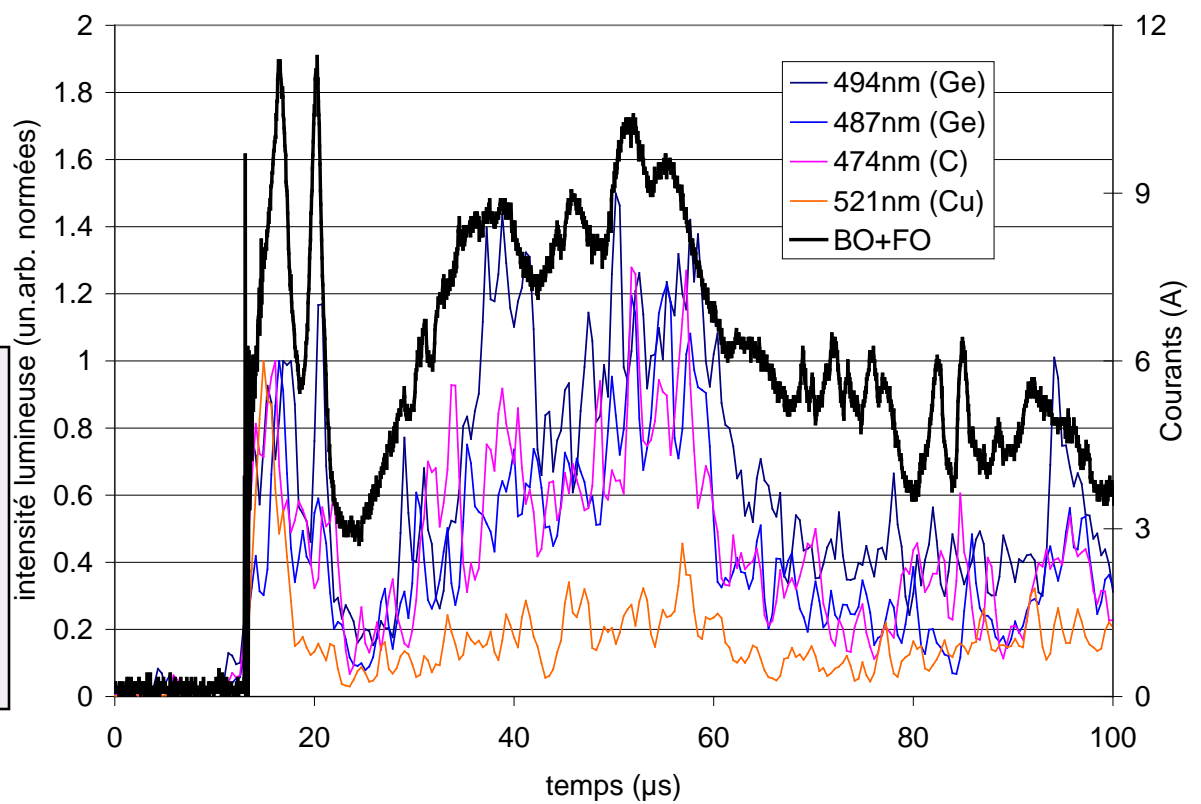




\section{Example of result : ESD87}

Spectrum of Discharge \#87

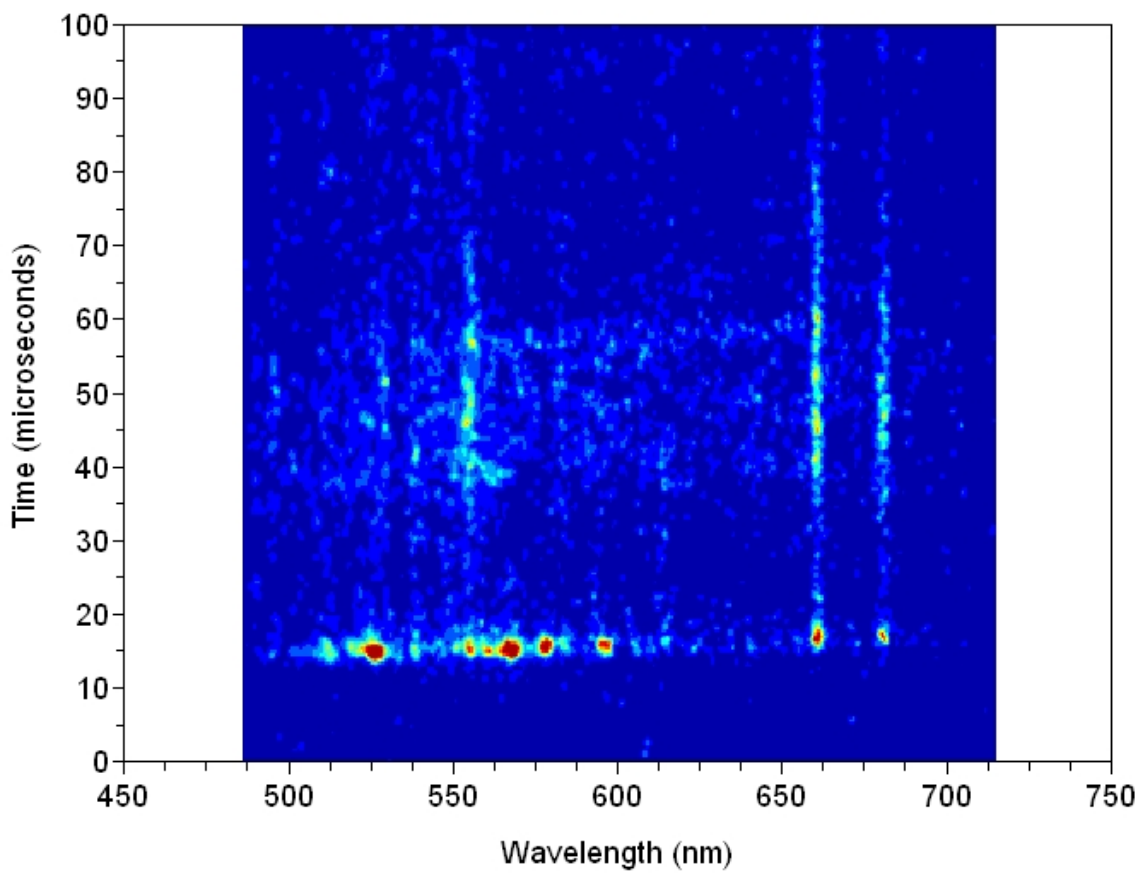

- spectrum very rich as the discharge begins, then only silver

- semi-conductor at the origin of the discharge but migrates to silver back electrode?

Observations of the cell's edge :

difficulties to identify different layers

overflowing glue was observed The cell was cut in the middle to obtain « ideal » sample well defined shape of the edge good identification of the layers no overflowing glue

$>$ Observations before and

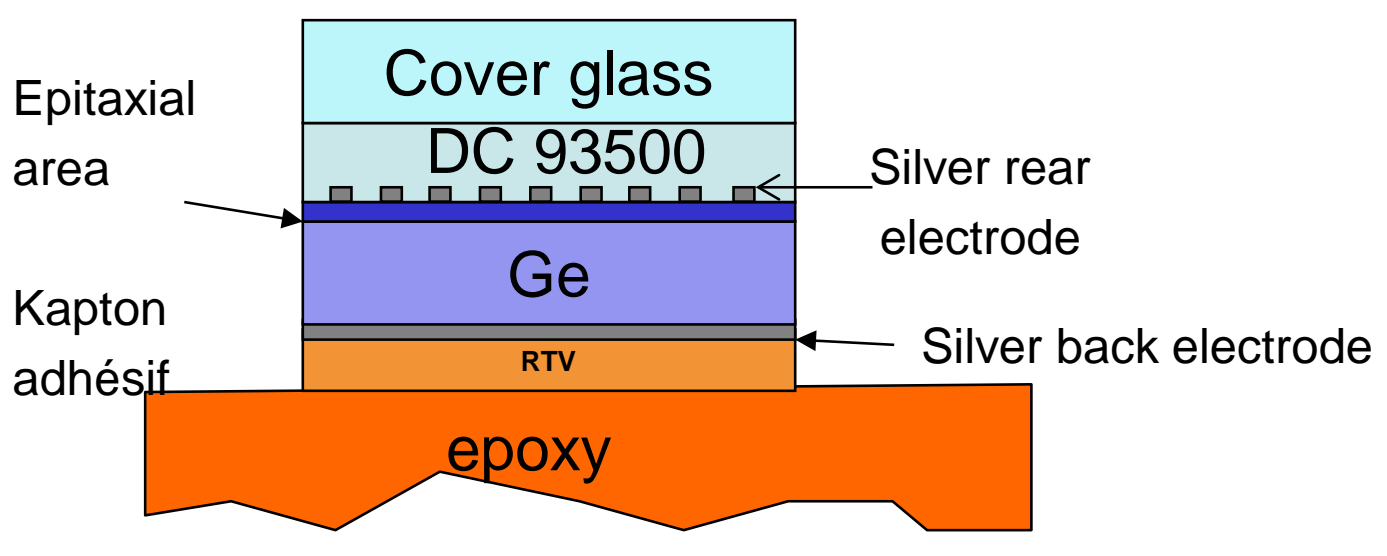
after ESD on side 1

$>$ Observations after ESD on side 2 


\section{SEM observations}

\begin{tabular}{|c|c|c|c|c|}
\hline $\begin{array}{c}\text { Side- } \\
\text { number }\end{array}$ & Csat/ Vsat & $\begin{array}{c}\text { Available energy } \\
\mathbf{1 / 2} \mathbf{C}_{\text {sat }} \mathbf{V}_{\text {bias }}{ }^{2}\end{array}$ & $\begin{array}{c}\text { Available charge } \\
\mathbf{C}_{\text {sat }} \mathbf{V}_{\text {bias }}\end{array}$ & ESD position \\
\hline $\mathbf{1 - 1}$ & $50 \mathrm{nF} /-500 \mathrm{~V}$ & $18.75 \mathrm{~mJ}$ & $75 \mu \mathrm{C}$ & Not identified \\
\hline $\mathbf{1 - 2}$ & $10 \mathrm{nF} /-500 \mathrm{~V}$ & $1.25 \mathrm{~mJ}$ & $5 \mu \mathrm{C}$ & Bottom of the cell \\
\hline $\mathbf{1 - 3}$ & $150 \mathrm{nF} /-500 \mathrm{~V}$ & $9 \mathrm{~mJ}$ & $30 \mu \mathrm{C}$ & Bottom \& top \\
\hline $\mathbf{2 - 1}$ & $100 \mathrm{nF} /-1100 \mathrm{~V}$ & $60.5 \mathrm{~mJ}$ & $110 \mu \mathrm{C}$ & Not identified \\
\hline $\mathbf{2 - 2}$ & $150 \mathrm{nF} /-500 \mathrm{~V}$ & $18.75 \mathrm{~mJ}$ & $75 \mu \mathrm{C}$ & Bottom \\
\hline $\mathbf{2 - 3}$ & $100 \mathrm{nF} /-1100 \mathrm{~V}$ & $60.5 \mathrm{~mJ}$ & $110 \mu \mathrm{C}$ & Bottom \\
\hline $\mathbf{2 - 4}$ & $100 \mathrm{nF} /-1400 \mathrm{~V}$ & $98 \mathrm{~mJ}$ & $80 \mu \mathrm{C}$ & Bottom \& top \\
\hline $\mathbf{2 - 5}$ & $100 \mathrm{nF} /-800 \mathrm{~V}$ & $32 \mathrm{~mJ}$ & $110 \mu \mathrm{C}$ & Top \\
\hline $\mathbf{2 - 6}$ & $100 \mathrm{nF} /-1100 \mathrm{~V}$ & $60.5 \mathrm{~mJ}$ & $96 \mu \mathrm{C}$ & $46.1 \mathrm{~mJ}$ \\
\hline $\mathbf{2 - 7}$ & $100 \mathrm{nF} /-960 \mathrm{~V}$ & & & \\
\hline
\end{tabular}

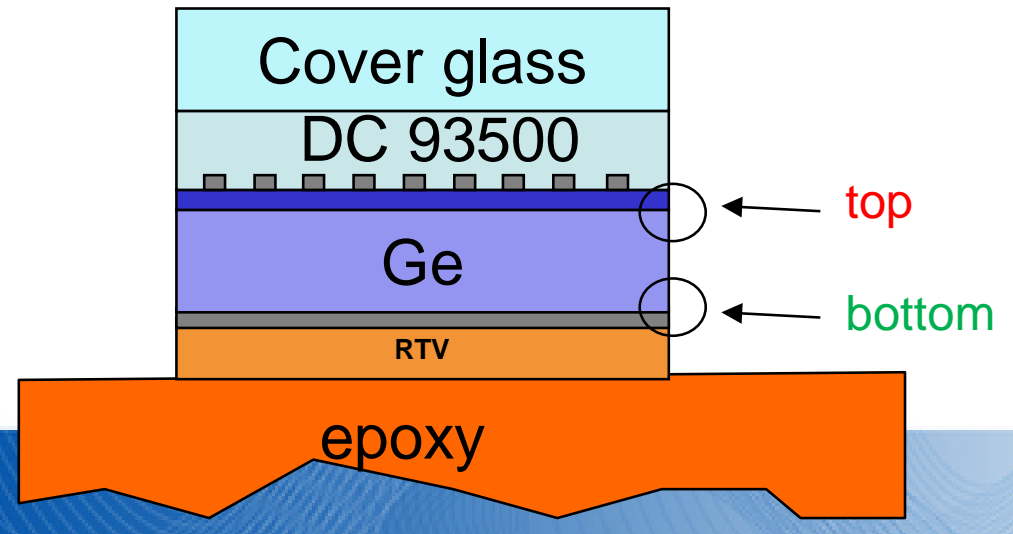




\section{ESD $1.3:$ " bottom »}

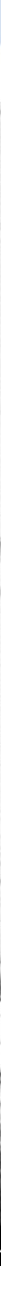

Tip on the silver ? 


\section{ESD 2.7 « Top »}

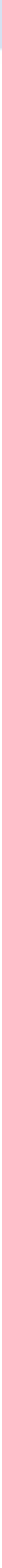




\section{ESD 2.1 « Top and bottom »}

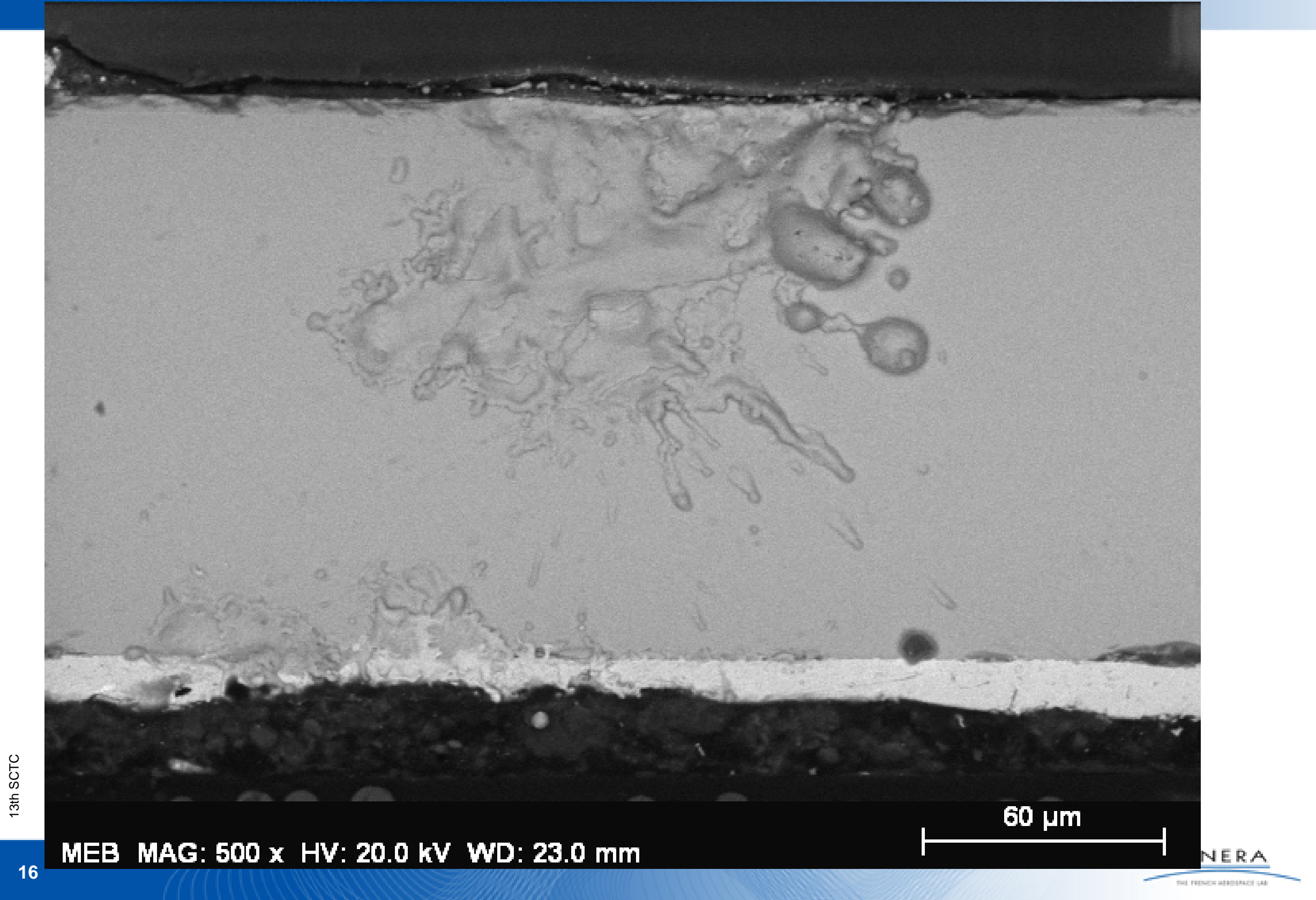




\section{CONCLUSIONS}

$>$ Position of ESDs : 2 types of triple point on solar cell's edge are possible

* Not only at the top where the triple point is made of semi-conductor/glue/vacuum

* Also at the bottom of the solar cell where triple point is constitued of silver/glue/vacuum.

* When it starts on the top, it can migrates to the silver back electrode :

\begin{tabular}{lllll}
\hline element & $\begin{array}{l}\text { Sp. } \\
\text { Heat } \\
\left(\mathbf{J} / \mathbf{k g}^{\star} \mathrm{K}\right)\end{array}$ & $\begin{array}{l}\text { Melt. } \\
\text { Temp. } \\
(\mathrm{K})\end{array}$ & $\begin{array}{l}\text { Boil. } \\
\text { Temp. } \\
(\mathrm{K})\end{array}$ & $\begin{array}{l}\text { Electr. } \\
\text { Cond. } \\
\left(\mathbf{\Omega}^{-\mathbf{1}} \cdot \mathbf{m}^{-\mathbf{1}}\right)\end{array}$ \\
\hline $\mathrm{Ag}$ & 230 & 1235 & 2435 & $6.10^{7}$ \\
$\mathrm{Ge}$ & 380 & 1211 & 3106 & 2 \\
\hline
\end{tabular}

* All parameters contribute to say that the cathode spot is more favorable on the silver than on the germanium (thermal and electrical point of view).

* Inputs for modelling and areas for mitigation

> Caracterisation of the discharge by triple probe gives coherent results

* Electron temperature independent from the distance

* Density decreasing with distance. Value compatible with literature. 